\title{
A környezeti fenntarthatóságra nevelés a bölcsődében
}

\author{
Darvay Saroltaa $^{1,2}$, Hill Katalin ${ }^{1}$, Fülöp Veronika ${ }^{1}$ és Venyingi Beáta ${ }^{1}$ \\ ${ }^{1}$ ELTE Eötvös Loránd Tudományegyetem Tanitó- és Óvóképzö Kar Természettudományi Tanszék \\ ${ }^{2}$ Selye János Egyetem Tanárképzö Kar Biológia Tanszék
}

\begin{abstract}
Absztrakt
A kisgyermeknevelők felelőssége, hogy a fenntarthatóságra nevelést a mindennapi gyakorlat részévé tegyék a bölcsődében. A fenntarthatóságra nevelés lehetővé teszi a nevelők és a gyermekek számára, hogy tiszteletben tartsák a természeti környezetet, aktív résztvevői legyenek a mindennapi élet adta lehetőségeknek. Kutatásunk területe a 0-3 éves korú gyermekek napközbeni ellátását végző intézményekben, a bölcsődékben zajló környezeti fenntarthatóságra nevelés megvalósulásának monitorozása a csecsemő- és kisgyermeknevelő hallgatók megítélése alapján. Az ELTE TÓK 242 csecsemő- és kisgyermeknevelő szakos, levelező tagozatos hallgatójának adatát dolgoztuk fel. Jelen tanulmányunkban a kutatási kérdések köréből az alábbi két témára koncentráltunk: a környezeti nevelés mely elemeit építik be a kisgyermeknevelők a mindennapi nevelő-gondozó bölcsődei gyakorlatukba; az egészségnevelés, egészséges szokásrendszer kialakítása mennyire jelenik meg az intézmény nevelö-gondozó munkájában. Az állítások megítélése ötfokú Likert-skálán történt. Az eredmények megítélése alapján a környezeti fenntarthatóság kérdésköre az intézmények életében megjelenik a bölcsődei nevelés-gondozás területén.
\end{abstract}

Kulcsszavak: fenntarthatóságra nevelés, egész intézményi megközelítés, egészségnevelés

\section{Bevezetés}

A fenntarthatóságra nevelés a változásról szól, a Földünkkel történő együttélésről és annak megváltozásáról. Állampolgárként meg kell értenünk, hogy miért van szükség a változásra, és hogyan tudjuk támogatni a mindenki számára fenntartható jövőkép elérését. Nem lesz könnyű a változás folyamata, de kisgyermekkori nevelőként, szülőként, oktatóként a gyermekek érdekében, mind jelenlegi lehetőségeik, mind jövőjük szempontjából, meg kell tennünk azokat a lépéseket, amelyek a változásokat elősegítik. A globális klímaváltozás miatt a kisgyermekek vannak a leginkább veszélyben. Különösen a kritikus, korai életévekben elszenvedett negatív epigenetikai hatások például az élelmezés- vagy vízbiztonság, a betegségek és a szélsőséges időjárási hatások élethosszig tartó hatásúak lehetnek (Currie \& Deschênes, 2016). 
A klímaváltozás tükrében elengedhetetlen a fenntarthatóság különböző dimenzióinak - természeti, társadalmi és gazdasági - megértése. A dolgok szokásos módon történő fenntartása már nem lehetséges. A fenntarthatóság érdekében végzett munka egy regeneráló folyamatot jelent a Föld rendszerei számára, amiben mindenkinek feladata van.

A Közös jövőnk címen megjelent Brundtland-jelentés (WCED, 1987) óta a fenntarthatóság fogalma fokozatosan elmozdult a komplexebb, globális értelmezés irányába. Az UNESCO (2010) fenntarthatósági koncepciója ezt a komplexitást szemlélteti, amely négy, sokféle módon egymásba kapcsolódó dimenziót jelenít meg, a környezeti (ökológiai, természeti), társadalmi, gazdasági és politikai dimenziót.

Az egymást követő nemzetközi jelentések (IPCC, 2018) rámutattak az éghajlatváltozás kihívásaira. A globális hőmérséklet két Celsius-fokos emelkedését manapság jelentős küszöbnek tekintik. Azt jósolták, hogy ezt a küszöböt túllépve a globális fenntarthatóság kezelésére irányuló jelenlegi erőfeszítések csak korlátozott hatásúak lesznek, és zavarok következnek be a környezeti, társadalmi és gazdasági rendszerben egyaránt.

\section{Kisgyermekkori nevelés a fenntarthatóság érdekében}

A fenntarthatóságra nevelés életünk, világunk több szintjét átalakító változásról szól, a gondolkodásunkról, az életmódunkról és a Föld regenerálását szolgáló cselekedeteinkről.

Az egész intézményi megközelítés megvalósítása nem könnyű feladat és nem gyors folyamat eredménye, pedig sürgős cselekvésre van szükség. Minden szinten együttmüködést igényel az egész intézményben, a szervezeti kultúra részeként kell megjelennie.

$\mathrm{Az}$ átalakító változásokban történő részvétel minden szinten kritikus gondolkodást igényel mind a nevelők, mind a gyermekek számára. Olyan kérdések felvetéséről van szó, amelyek a gondolkodásunk és a létezésünk különböző módjait vitatják meg. Ezek önmagukban is hasznosak, de nem elegendők, támogatniuk kell a változások előmozdítását és jelentős szerepet kell játszaniuk az intézményes nevelés helyszínein, a gyermekekkel, családokkal és közösségekkel folytatott cselekvés előmozdításában és megvalósításában (ACARA, 2018).

Az egész intézményi megközelítés értelmezése szerint a fenntarthatóság kérdésköre feladata a kisgyermekkori nevelésnek. A fenntarthatóság a Bölcsődei nevelés-gondozás országos alapprogramjának (2017) fontos részét képezi, és ezt be kell építeni az intézmény saját szakmai protokolljába, a szolgáltatás minden egyes elemébe. A fenntarhatóságra nevelés tehát kiterjed az épített és természeti környezetre, az intézményi nevelö-gondozó munka minden területére, figyelembe véve a kisgyermekkor élettani és pszichológiai jellemzőit. A bölcsődében az egészséges környezet biztosítása (bölcsőde helyiségei, udvara), a jól megválasztott napirend, a helyes életritmus kiala- 
kítása, az élettani szükségletnek megfelelő mennyiségi és minőségi étkezés biztosítása, az egészségvédelem, az egészséges életmód megalapozása, mind a harmonikus testi és lelki fejlődéséhez szükséges alapfeltételek, melyek a bölcsődei nevelés-gondozás legfontosabb feladatai közé tartoznak (Darvay, 2015).

Az Oktatási Hivatal által 2016-ban megjelent útmutató szerint az eddigi nyolc kisgyermeknevelői kompetencia egy újabb kompetenciával egészült ki. A kilencedik kompetencia „a környezeti nevelésben mutatott jártasság, a fenntarthatóság értékrendjének hiteles képviselete és a környezettudatossághoz kapcsolódó attitűdök átadásának módja” elnevezést kapta $(\mathrm{OH}, 2016)$.

A fenntarthatóság környezeti/ökológiai/természeti dimenziója a kisgyermekkori nevelés színterén a környezeti nevelést jelenti. A környezet és a természeti rendszerek működésének megismerését, megbecsülését, tiszteletét jelenti. Ez az, amire szükségünk van a túléléshez és a jól-léthez, közvetlenül kapcsolódva a természeti környezethez.

A kisgyermeknevelők felelőssége, hogy a fenntarthatóságra nevelést a mindennapi gyakorlat részévé tegyék. A fenntarthatóságra nevelés lehetővé teszi a nevelők és a gyermekek számára, hogy előmozdítsák a felelősségvállalás alakulását, tiszteletben tartsák a természeti környezetet, aktív résztvevői legyenek a mindennapi élet adta lehetőségeknek. A nevelők és a gyermekek együtt dolgoznak a környezet megismerésében, az erőforrások fenntartható felhasználásának előmozdításában, valamint a fenntartható gyakorlatok kidolgozásában és végrehajtásában. Ebben a folyamatban az intézmény minden alkalmazottjának mintaadó szerepe van. Ezért biztosítani kell a rendszeres továbbképzések lehetőségét mindenki számára.

Az eddigi gyakorlat igazolja, hogy a fenntarthatóságra nevelés integrálása az intézmény életébe az ott dolgozó vezetők és pedagógusok elhivatottságán, lelkesedésén, meggyőződésén is múlik. Ezt kell megerősíteni, támogatni a kompetenciafejlesztő tréningeken/workshopokon, továbbképzéseken, szakmai látogatásokon való részvétellel, hogy minél több elméleti és gyakorlati vonatkozásokat megismerjenek a fenntarthatóságra nevelés három dimenziójáról, a globális és lokális problémákról és megoldásokról (Gan et al., 2019; Varga \& Könczei, 2019).

\section{A kutatás célja}

Kutatásunk területe a 0-3 éves korú gyermekek napközbeni ellátását végző intézményekben, a bölcsődékben zajló környezeti fenntarthatóságra nevelés megvalósulásának kutatása a csecsemő- és kisgyermeknevelő hallgatók megítélése alapján.

Kutatásunkban azt a célt tűztük ki, hogy megtudjuk, az ELTE TÓK csecsemő- és kisgyermeknevelő szakos, levelező tagozatos hallgatói, hogyan értékelik a környezeti fenntarthatóság megvalósítását a hazai bölcsődei intézményes nevelés mindennapjaiban. 


\section{A kutatás kérdései}

A konkrét kutatási kérdések a következők voltak:

- Az egész intézményi megközelítés a bölcsődei fenntarthatóság elveinek megvalósítása terén kiterjed-e az épített és természeti környezetre, az intézményi nevelö-gondozó munka minden területére, figyelembe véve a kisgyermekkor élettani és pszichológiai jellemzőit?

- Integrálja-e a bölcsőde a fenntartható fejlődés környezeti, társadalmi és gazdasági dimenzióit nevelés-gondozás gyakorlatában?

- Hogyan valósul meg a környezeti fenntarthatóság elve a bölcsődei intézmény üzemeltetésének egyes területein?

- A környezeti nevelés mely elemeit építik be a kisgyermeknevelők a mindennapi nevelö-gondozó bölcsődei gyakorlatukba?

- Az egészségnevelés, egészséges szokásrendszer kialakítása mennyire jelenik meg az intézmény nevelö-gondozó munkájában?

- Biztosítják-e a bölcsődei kisgyermeknevelők az összes érdekelt fél aktív részvételét a környezeti nevelési programok megvalósításában (például a gyermekeket, a szülőket, helyi közösségeket)?

- A kutatásban részt vevő hallgatók mennyire értékelik saját magukat környezettudatosnak, egészségtudatosnak?

Az adatokat 2018 tavaszán és 2019 januárjában kérdőíves módszerrel gyűjtöttük a második és harmadik évfolyamos, levelező tagozatos, csecsemő- és kisgyermeknevelő szakos hallgatók körében.

A hallgatók feladata az volt, hogy azt a bölcsődét véleményezzék, ahol a bölcsődei nevelési gyakorlatukat végzik. Az ELTE TÓK levelező hallgatói maguk választanak gyakorlati helyszínt a képzés során. A hallgatók többsége a Közép-magyarországi Régióban él, és dolgozik.

A mintánk elemszáma 242 fő, 125 másodéves, 117 harmadéves hallgató. Háttér-információk a hallgató életkora, neme, bölcsődei gyakorlatának helyszíne (fóváros, kerület, város, község), a levelező hallgatók munkahelye (bölcsődében dolgozik, nem dolgozik bölcsődében).

Életkoruk 20 és 61 év között volt. Az átlag életkor 37,42 év volt, valamenynyien nők.

A hallgatók 62\% -a (165 fö) bölcsődében dolgozott a képzés alatt, az ott eltöltött munkaévek száma 10,89 év, legkevesebb 1, leghosszabb munkában eltöltött idő 38 év volt, 94\%-uk kisgyermeknevelőként dolgozott (nem BA végzettséggel), $3 \%$-uk vezető beosztásban dolgozott a bölcsődében. A megkérdezett hallgatók 38\%-a (77 fö) nem dolgozott bölcsődében a mintavétel időpontjában.

A vizsgálatban részt vevő hallgatók 38\%-a hallott a „zöld bölcsőde” programról, azaz 62\%-a a hallgatóknak még nem.

A hallgatók 63\%-a végzi a bölcsődei szakmai gyakorlatát a fóvárosban a képzés ideje alatt, 35\%-a városban, $2 \%$-a községben. A mintában szereplő településtípusok megoszlása értelmében a vizsgálat eredményei többnyire a 
főváros bölcsődéinek munkájáról adnak képet. A főváros 23 kerülete közül kiemelten a legmagasabb arányban a 11. kerület szerepelt a szakmai gyakorlat helyszíneként 23\%-kal, ezt követi a 3. kerület 12\%-kal, majd a 13. és a 14 . kerület 7\%-kal.

A résztvevők a környezeti nevelés általunk vizsgált elemeit (33 elem) ötfokú Likert-skálán (1-5) értékelték, az elem tényleges megvalósításának ismeretében (1-nem teljesül, 5-teljes mértékben teljesül). Külön jelölték, amennyiben nem tudták megítélni az adott vizsgált elem megvalósulását. A környezeti nevelés elemeinek értékelése és a háttér-információk képezték a mennyiségi adatokat. Kiszámoltuk az ötfokú Likert-skálán történt értékelések főbb statisztikai paramétereit (elemszám, minimum, maximum, átlag, szórás).

\section{Eredmények}

Jelen tanulmányunkban az anyag és módszer részben ismertetett kutatási kérdések köréből az alábbi két kérdésre koncentrálunk:

- A környezeti nevelés mely elemeit építik be a kisgyermeknevelők a mindennapi nevelö-gondozó bölcsődei gyakorlatukba?

- Az egészségnevelés, egészséges szokásrendszer kialakítása mennyire jelenik meg az intézmény nevelő-gondozó munkájában?

A vizsgálatban rész vevő hallgatók száma $\mathrm{N}=242$ fő volt, az eredményeket összefoglaló táblázatokban szereplő válaszadók elemszáma ellenben 203 és 232 között változik attól függően, hogy az adott állítást hányan tudták megítélni.

\section{A környezeti neveléssel összefüggö állitások értékelése}

A kutatásban részt vevő levelezős hallgatók válaszai alapján a környezeti nevelés megvalósulásának értékelése a mindennapi nevelő-gondozó bölcsődei gyakorlatban az alábbiak szerint értelmezhető. (1. táblázat) A táblázatban szereplő statisztikai paraméterek az 5 fokú Likert-skála értékei alapján számolt mutatók. 
1. táblázat

A környezeti nevelés megvalósulása a kisgyermeknevelök nevelö-gondozó bölcsődei munkájában kérdéskörre vonatkozó állitások statisztikai paraméterei

\begin{tabular}{|l|c|c|c|c|c|}
\hline \multicolumn{1}{|c|}{ Környezeti nevelés } & N & Min. & Max & Átlag & Szórás \\
\hline $\begin{array}{l}\text { K1 A bölcsődei nevelés küldetésének tartja, } \\
\text { hogy helyi környezeti nevelési programja } \\
\text { legyen }\end{array}$ & 215 & 1 & 5 & 3,27 & 1,216 \\
\hline $\begin{array}{l}\text { K4 A bölcsőde minden dolgozója képviseli a } \\
\text { környezettudatosság modelljét. }\end{array}$ & 210 & 1 & 5 & 2,86 & 1,106 \\
\hline $\begin{array}{l}\text { K19 Megtörténik a gyermekek bevonása a } \\
\text { környezet megóvásába }\end{array}$ & 227 & 1 & 5 & 3,35 & 1,226 \\
\hline $\begin{array}{l}\text { K20 Megvalósul a kötődés kialakulásának } \\
\text { lehetősége a természet elemeihez: növé- } \\
\text { nyekhez, állatokhoz, kövekhez, vízhez }\end{array}$ & 223 & 1 & 5 & 3,18 & 1,207 \\
\hline $\begin{array}{l}\text { K21 Megvalósulnak a kreatív játékok a ter- } \\
\text { mészetben, szabadban }\end{array}$ & 233 & 1 & 5 & 3,48 & 1,145 \\
\hline $\begin{array}{l}\text { K22 Megvalósulnak a szenzitív/érzékszervi } \\
\text { játékok a természetben, szabadban }\end{array}$ & 229 & 1 & 5 & 3,31 & 1,180 \\
\hline $\begin{array}{l}\text { K23 A bölcsőde rendelkezik természet- és/ } \\
\text { vagy madárbarát kerttel }\end{array}$ & 216 & 1 & 5 & 2,59 & 1,522 \\
\hline $\begin{array}{l}\text { K27 A mesék, játékok kapcsán formálódik } \\
\text { az érzelmi viszonyulás, erősödik a termé- } \\
\text { szetszeretet, természettisztelet, természet- } \\
\text { védelem }\end{array}$ & 225 & 1 & 5 & 3,82 & 1,076 \\
\hline $\begin{array}{l}\text { K28 Társas környezetben formálódik az: } \\
\text { együttmúködés, szolidaritás, empátia és } \\
\text { egymás iránti tisztelet, segítés, szeretet } \\
\text { tanulása. }\end{array}$ & 228 & 1 & 5 & 4,18 &, 928 \\
\hline $\begin{array}{l}\text { K33 A kisgyermeknevelök készítenek hul- } \\
\text { ladék újrahasznosításával játékokat, díszítő } \\
\text { elemeket }\end{array}$ & 203 & 1 & 5 & 2,84 & 1,419 \\
\hline
\end{tabular}

Az általunk megjelölt 10 állításból a legmagasabb értéket a megvalósulás megítélésében a Társas környezetben formálódik az együttmüködés, szolidaritás, empátia és egymás iránti tisztelet, segités, szeretet tanulása elem kapta (átlag 4,18). A mesék, játékok kapcsán formálódik az érzelmi viszonyulás, erösödik a természetszeretet, természettisztelet, természetvédelem elem (átlag 3,82) hasonlóan magas értékelést kapott. Ezt követik az alábbiak: Megvalósulnak a kreativ játékok a természetben, szabadban (átlag 3,48), Megtörténik a gyermekek bevonása a környezet megóvásába (átlag 3,35), Megvalósulnak a szenzitiv/érzékszervi játékok a természetben, szabadban (átlag 3,31), A bölcsödei nevelés küldetésének tartja, hogy helyi környezeti nevelési program- 
ja legyen (átlag 3,27), Megvalósul a kötödés kialakulásának lehetösége a természet elemeihez: növényekhez, állatokhoz, kövekhez, vízhez (átlag 3,18), A kisgyermeknevelők készitenek hulladék újrahasznosításával játékokat, díszítő elemeket (átlag 2,84), A bölcsőde rendelkezik természet- és/vagy madárbarát kerttel (átlag 2,59).

Minden intézmény a saját keretein belül tervezi a környezettudatosság megvalósulásának lehetőségeit. Az intézmény adottságai természetesen behatárolják a lehetőségeket. Ezek a tendenciák az eredményeink alapján is kirajzolónak, erre utalnak az átlagokhoz tartozó szórásértékek is.

\section{Az egészségneveléssel összefüggö állitások értékelése}

\section{2. táblázat}

Az egészségnevelés, egészséges szokásrendszer kialakitásának megvalósulása a kisgyermeknevelók nevelö-gondozó bölcsődei munkájában kérdéskörre vonatkozó állítások statisztikai paraméterei

\begin{tabular}{|l|c|c|c|c|c|}
\hline \multicolumn{1}{|c|}{ Egészségnevelés } & N & Min. & Max & Átlag & Szórás \\
\hline $\begin{array}{l}\text { K2 A bölcsődei nevelés küldetésének tart- } \\
\text { ja, hogy helyi egészségnevelési programja } \\
\text { legyen }\end{array}$ & 216 & 1 & 5 & 3,72 & 1,124 \\
\hline $\begin{array}{l}\text { K5 A bölcsőde minden dolgozója képviseli } \\
\text { az egészségtudatosság modelljét. }\end{array}$ & 209 & 1 & 5 & 3,21 & 1,058 \\
\hline $\begin{array}{l}\text { K14 Rendelkezik a gyermekek számára is } \\
\text { elérhető kerttel (veteményeskert, gyógynö- } \\
\text { vénykert) }\end{array}$ & 223 & 1 & 5 & 2,39 & 1,683 \\
\hline $\begin{array}{l}\text { K15 Lehetőség van a rendszeres szabad } \\
\text { levegőn tartózkodásra, udvari játékra }\end{array}$ & 235 & 1 & 5 & 4,44 & 1,109 \\
\hline K16 Lehetőség van rendszeres kint alvásra & 231 & 1 & 5 & 2,61 & 1,733 \\
\hline $\begin{array}{l}\text { K18 Biztonságos a bölcsőde épülete, udvara, } \\
\text { kertje }\end{array}$ & 232 & 1 & 5 & 3,86 & 1,176 \\
\hline
\end{tabular}

Az egészségnevelés, egészséges szokásrendszer kialakítása kérdéskörben szereplő 6 állítás közül a legmagasabb értéket a Lehetőség van a rendszeres szabad levegön tartózkodásra, udvari játékra (átlag 4,44) elem kapta, ezt követik az alábbiak Biztonságos a bölcsőde épülete, udvara, kertje (átlag 3,86), A bölcsődei nevelés küldetésének tartja, hogy helyi egészségnevelési programja legyen (átlag 3,72), A bölcsőde minden dolgozója képviseli az egészségtudatosság modelljét (átlag 3,21), Lehetöség van rendszeres kint alvásra (átlag 2,61). Ami az alacsony értéket illeti, Budapest viszonylatában nem meglepő, hiszen a levegő összetétele nem teszi lehetővé mindenhol ennek megvalósítását. A Rendelkezik a gyermekek számára is elérhetö kerttel (veteményeskert, gyógynövénykert) (átlag 2,39) elem kapta a legalacsonyabb értéket. (2. táblázat) 
Az egészségtudatosság a bölcsődei nevelés-gondozás alapértékei között szerepelt az intézményrendszer megalakulása óta. A lehetőségek bővítése, elmélyítése lehet a további feladat.

\section{A vizsgálatban részt vett levelezö tagozatos hallgatók vélekedése saját környezettudatosságukról, saját egészségtudatosságukról}

A kutatás további kérdése volt, hogy a vizsgálatban részt vett levelező tagozatos hallgatók hogyan vélekednek saját környezettudatosságukról, saját egészségtudatosságukról. Minkettő megítélésében nagyon pozitívan nyilatkoztak. Az egészségtudatosságukat magasra értékelték (átlag 4,25), a környezettudatosságuk megítélése sem maradt el ettől számottevően (átlag 4, 17).

A Likert-skála értékei alapján az egészségtudatosság megítélésében a 4-es és az 5-ös kategória egyenlő arányban oszlik meg (42\%). A környezettudatosság tekintetében a 4-es kategóriában van a választ adók 53\%-a, míg az 5-ös kategóriában a 33\%-a. (1. ábra) Összességében 80\%-ban pozitívan nyilatkoztak a megkérdezett hallgatók a saját tudatosságukat illetően.

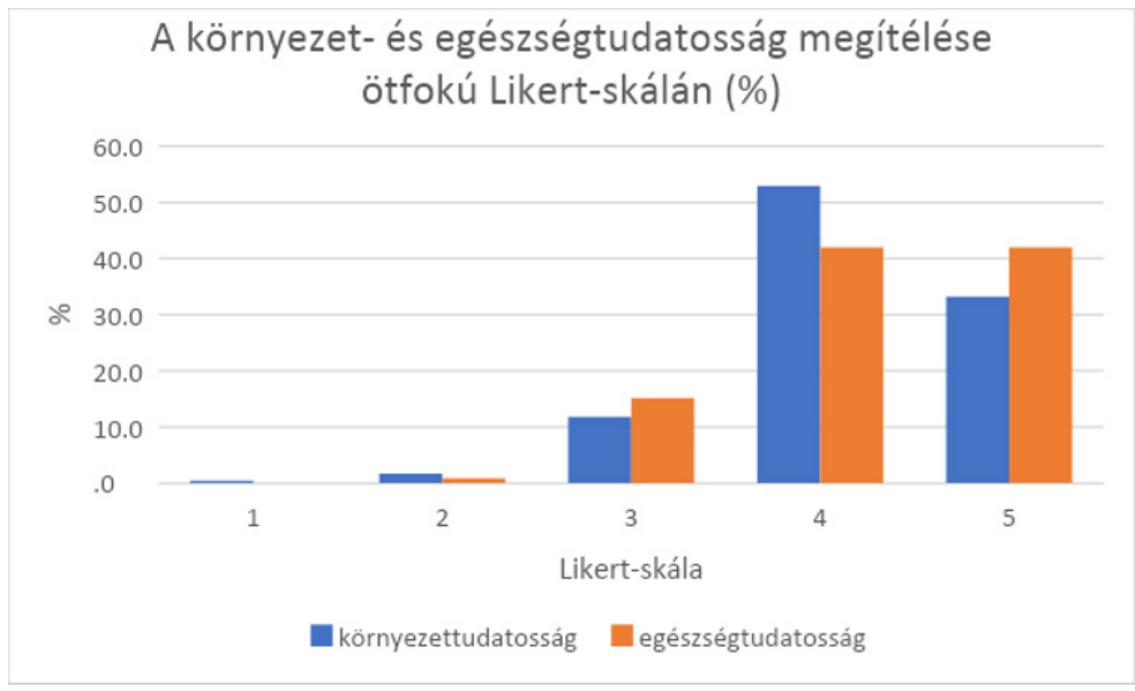

1. ábra

A környezet-és egészségtudatosság megitélése ötfokú Likert-skálán

A kutatásunk korlátait az alábbi három megállapításban összegezzük. 1. Nem az intézmények szakemberei, hanem a hallgatói vélemények alapján történt a bölcsődék megítélése. 2 . A kutatás résztvevőinek száma nem teszi lehetővé az adatok mélyebb elemzését, statisztikai számítások elvégzését. 3. Kizárólag a Közép-magyarországi Régióban vizsgált bölcsődékre, ezen belül 
a főváros bizonyos kerületeire vonatkozik a megállapítások többsége. Vizsgálatunk nem tekinthető reprezentatívnak.

A korlátok ellenére mégis fontosnak tartjuk ráirányítja a hallgatók figyelmét a fenntarthatóság kérdéskörére. A kutatás által megismerték az egész intézményes megközelítés elvét és a megvalósítás lehetőségeit, a környezetkultúra jelentőségét, a gyermek és a természet kapcsolatának fontosságát. Kutatásunk jelentős hozadéka a kisgyermeknevelő hallgatók számára, hogy a téma iránti érzékenyítés és szemléletformálás megvalósult.

\section{Összefoglalás}

A fenntarthatóságra nevelés célja, hogy felhatalmazza a polgárokat a pozitív környezeti és társadalmi változásokra való fellépésre azáltal, hogy ismereteket és készségeket ad az embereknek, hogy új megoldásokat találjanak társadalmi, gazdasági és környezeti problémáik kérdéseire (Otieno, 2008).

A biodiverzitás csökkenés, az éghajlatváltozás és a természetes életfenntartó rendszerek problémái az ökológiailag fenntarthatatlan fejlődés jelei (Millenium Ecosystem Assissment, 2005; Rockström et al., 2009; Sale, 2011). A társadalmi fenntarthatóság alapja az Emberi Jogok Egyetemes Nyilatkozata. A társadalmi fenntarthatóság hangsúlyozza az emberi méltóságot és a szolidaritást, elősegíti a befogadást, a részvételt, a társadalmi identitást és a társadalmi kompetenciát, ami a kora gyermekkori nevelésben különösen hangsúlyosan van jelen (Boström, 2012; Murphy, 2012; Salonen et al., 2013a).

Alapvetően a fenntarthatóság egzisztenciális kérdés, amely a globális közösség minden emberét bevonja. Ezért a fenntartható fejlődés nemcsak a viselkedésminták megváltoztatását igényli a környezettel és a társadalommal kapcsolatban, hanem az emberi viselkedést formáló szélesebb rendszerek megváltoztatását is (Haughton, 1999). Ehhez meg kell változtatni a jóléti paradigmákat az anyagi javak felhalmozódásától a harmónia, koherencia és tudatosság felé kell elmozdulni (Salonen \& Åhlberg, 2013b). Az oktatásnak nagy szerepe van ebben a társadalmi változásban. A kora gyermekkori nevelők tudatosan és nem tudatosan, a tudat alattin adják át gyermekeiknek tudásukat, értékeiket, attitüdjüket (Salonen et al., 2013a).

A kora gyermekkori nevelés és gondozás (Early Childhood Education and Care, ECEC) alapelveinek négy fö szempontja: a társadalom, a gyermekek, a szülők és a pedagógusok. A kisgyermekkori fenntarthatóságra nevelés területeit a Bölcsődei nevelés-gondozás országos alapprogramjára (2017) épülő helyi program határozza meg, amelyben különös jelentőséggel bírnak a fenntarthatósági célok társadalmi vonatkozásai.

Az Európai Unió Tanácsa a magas színvonalú kora gyermekkori nevelési és gondozási rendszerekről az alábbiak szerint nyilatkozik a 2019-es Ajánlásában: a magasabb szintű kompetenciafejlesztés és az oktatás sikerének előfeltétele, hogy a korai életévekben lerakják a szilárd alapokat, ami a gyermekek egészsége és jól-léte szempontjából is alapvető jelentőségü. Ezért a 
kisgyermekkori nevelésre és gondozásra úgy kell tekinteni, mint az oktatási és képzési rendszerek alapjaira, és annak a teljes oktatási lánc szerves részét kell képeznie (EU COM, 2019).

A születéstől a hat évig terjedő évek fontosságát elismerték a gyermek fejlődésének kritikus tanulási időszakaként (Tilbury et al., 2005). A kutatások megerősítik a korai évek fontosságát a gyermekek hosszú távú pozitív befolyásolásában, a gyermekek értékorientációjának kialakulásában. A kora gyermekkori nevelés területe felismeri a fenntarthatósági célok megvalósításának fontosságát a kisgyermekek életében (Samuelsson \& Kaga, 2010). Ez megerősíti azt az álláspontot, miszerint a fenntarthatóságra nevelést is a korai életszakaszban kell elkezdeni. Így a kora gyermekkori nevelők óriási potenciállal rendelkeznek az értékek, attitüdök, készségek és magatartás formálásában, amelyek támogatják a fenntarthatósági célok megvalósítását, mint például az interkulturalitás, a méltányosság, a nemek közötti egyenlőség, a demokrácia és a természeti erőforrások felhasználása (Davis \& Gibson, 2006; Wells \& Lekies, 2006).

Magyarországon a kora gyermekkor értelmezése eltér a fent említett szakirodalmi utalásoktól, a nemzetközi gyakorlattól. Megkülönböztetünk kisgyermekkori nevelést és óvodai nevelést. A kisgyermekkori nevelés, ami a 0-3 éves kort öleli fel, intézménye a bölcsőde, mini bölcsőde, szolgáltatások keretében pedig a munkahelyi bölcsőde és a családi bölcsőde. A nevelést végző szakemberek a kisgyermeknevelők, segítőik a bölcsődei dajkák.

Örömmel nyugtáztuk, hogy Magyarországon új dimenzióval bővült a kisgyermekkori nevelés programja. A magyarországi kisgyermeknevelők kompetenciái közé került a fenntarthatóság értékrendjének hiteles képviselete és a környezettudatossághoz kapcsolódó attitűdök átadásának módja, a környezeti nevelésben mutatott jártasság. Hazánkban a 3-6 éves korú, óvodás gyermekek környezeti nevelése nagy múltra tekint vissza, ami a 2000-ben induló magyar ökoiskolai program mintájára épült (Varga \& Havas, 2018).

2006 áprilisától a környezetvédelemért és az oktatásügyért felelős tárcák közösen hirdették meg a Zöld Óvoda pályázatot. Háromévenként lehet pályázni a cím elnyerésére, majd ezután, kilenc év környezeti nevelőmunkájának a bemutatásával lehet pályázni az örökös Zöld Óvoda címre (Bihariné \& Kanczler, 2019; Vargáné, Pálfi, Szerepi, \& Molnár, 2018).

Számos hazai bölcsőde életében évek óta jelen van a „Zöld Bölcsőde” program, melyben kiemelt figyelmet fordítanak a környezetvédelemre, a környezeti nevelésre. A program célja, környezettudatos szemlélet és magatartásformák megalapozása. A bölcsődei szakemberek jelentős lépéseket tesznek annak érdekében, hogy a hazánkban meglévő, a nemzetközi mércével mérve is magas színvonalú és elismert környezeti nevelés a kisgyermekkori nevelésben is a nevelés-gondozás egyik sarokpontja legyen.

A csecsemő-és kisgyermeknevelő BA-képzés feladata, hogy a nappali és levelező tagozatos hallgatók és a továbbképzésen részt vevő kollégák egyaránt a legszínvonalasabb elméleti és gyakorlati képzésben részesüljenek a fenntarthatóságra nevelés tárgykörében. 


\section{Irodalom}

ACARA. Australian Curriculum and Reporting Authority. (2018). Australian Cross Curriculum Priorities. www.australiancurriculum.edu.au/f-10-curriculum/ cross-curriculum-priorities/sustainability/ (2020.10.27.)

Bihariné Krekó, I. \& Kanczler Gy. (2019). A környezeti nevelés előzményei és jellemzői. In Vitályos, G. Á. (Ed.), Az óvodai környezeti nevelés módszertana (pp.11-21). ELTE TÓK., http://www.eltereader.hu/media/2019/03/TOK_ Ovodai_2019_02_22_WEB.pdf (2020.10.27.)

Bölcsődei nevelés-gondozás országos alapprogramja, 2017

https://www.magyarbolcsodek.hu/files/shares/Bolcsodei\%20nevelesgondozas\%20orszagos\%20alapprogramja\%202017..pdf (2020.10.27.)

Currie, J. \& Deschênes, O. (2016). Children and Climate Change: Introducing the Issue. The Future of Children, 26(1), 3-9.

https://doi.org/10.1353/foc.2016.0000

Boström, M. (2012). A missing pillar? Challenges in theorizing and practicing social sustainability: introduction to the special issue. Sustainability: Science, Practice, E Policy, 8(1), 3-14.

https://doi.org/10.1080/15487733.2012.11908080

Darvay, S. (2015). A kisgyermekek egészséges szokásrendszerének kialakítása a családban. In Nyitrai, Á. (Ed.), Kisgyermekek nevelése a családban és a bölcsödében (pp. 31-40). Kaposvári Egyetem Pedagógiai Kar.

Davis, J. \& Gibson, M. (2006). Embracing Complexity: Creating Cultural Change through Education for Sustainability. International Journal of Knowledge, Culture and Change Management, 6(2), 92-102.

https://doi.org/10.18848/1447-9524/CGP/v06i02/49932

EU COM (2019). A Tanács Ajánlása a magas színvonalú kisgyermekkori nevelési és gondozási rendszerekről (2019/C 189/02) https://eur-lex.europa.eu/legalcontent/HU/TXT/PDF/?uri=CELEX:32019H0605(01)\&from=EN (2020.10.27.)

Gan, D., Gal, A., Könczey, R. \& Varga, A. (2019). Do eco-schools really help implementation of ESD? A comparison between eco-school systems of Hungary and Israel. Hungarian Educational Research Journal, 9(4), 628-653. https://doi. org/10.1556/063.9.2019.4.53

IPCC. Intergovernmental Panel on Climate Change. (2018). Global Warming of $1.5^{\circ} \mathrm{C}$. http://ipcc.ch/ (2020.10.27.)

Millennium Ecosystem Assessment. (2005). Ecosystems and Human Well-being: Synthesis. Island Press. https://www.millenniumassessment.org/documents/ document.356.aspx.pdf (2020.10.27.)

Murphy, K. (2012). The social pillar of sustainable development: a framework for policy analysis. Sustainability: Science, Practice, E Policy, 8(1). 15-29.

https://doi.org/10.1080/15487733.2012.11908081 (2020.10.27.) 
Oktatási Hivatal (2016). Kiegészitö Útmutató az Oktatási Hivatal által kidolgozott Útmutató a pedagógusok minösitési rendszeréhez címü felhasználói dokumentáció értelmezéséhez. A bölcsödében, mini bölcsődében pedagógus munkakörben foglalkoztatottak részére. https://www.oktatas.hu/pub_bin/dload/pem/bolcsode. $\operatorname{pdf}(2020.10 .27$.)

Otieno, L. (2008). The role of culture in integration of education for sustainable development in early childhood education. The role of early childhood education for a sustainable society, 46-49. Gothenburg University. http://www.ufl.gu.se/ digitalAssets/837/837347_Workshop_May07_papers.pdf (2020.10.27.)

Rockström, J., Steffem, W., Noone, K., Persson, Å., Stuar Chapin III, F., Lambin, E. F. \& Foley, J. A. (2009). A safe operating space for humanity. Nature, 461, 472-475. http://dx.doi.org/10.1038/461472a

Sale, P. F. (2011). Our Dying Planet. An Ecologist's View of the Crisis We Face. University of California Press.

https://doi.org/10.1525/9780520949836

Salonen, A., Tast, S. \& Hakari, S. (2013a). Finnish Early Childhood Educators and Sustainable Development. Journal of Sustainable Development, 6(2), 70-85. https://doi.org/10.5539/jsd.v6n2p70

Salonen, A. \& Åhlberg, M. (2013b). Towards sustainable society - From materialism to post-materialism. International Journal of Sustainable Society, 5(4), http://dx.doi.org/10.1504/IJSSOC.2013.056846

Samuelsson, I. \& Kaga, Y. (2010). Early Childhood Education to Transform Cultures for Sustainability. In Assadourian, L. Starke, \& L. Mastny (Eds.), State of the World 2010: Transforming Cultures: From Consumerism to Sustainability (pp. 57-82). Worldwatch.

Tilbury, D., Coleman, V. \& Garlick, D. (2005). A National Review of Environmental Education and its Contribution to Sustainability in Australia: School Education. Australian Government Department of the Environment and Heritage and Australian Research Institute in Education for Sustainability (ARIES). http:// aries.mq.edu.au/projects/national_review/files/volume2/Volume2_Final05.pdf (2020.10.27.)

UNESCO. (2010). Four Dimensions of Sustainable Development. www.unesco.org/ education/tlsf/mods/theme_a/popups/mod04t01s03.html. (2020.10.27.)

Varga, A. \& Havas, P. (2018). ENSI and its impact on the Hungarian educational system. In Affolter, C. \& Varga, A. (Eds.), Environment and school initiatives lessons from the ENSI network - Past, present and future (pp. 142-148). ENSI/ EKE-OFI. http://www.education21.ch/sites/default/files/uploads/pdf-d/ news21/Lessons_from_the_ENSI_Network-book_web.pdf (2020.10.27.)

Varga, A. \& Könczey, R. (2019). Which ways of evaluation of education for sustainability is acceptable for Hungarian teachers? Hungarian Educational Research Journal, 9(4), (pp. 654-667). 
https://doi.org/10.1556/063.9.2019.4.54

Vargáné Nagy A., Pálfi S., Szerepi S. \& Molnár B. (2018). Fenntartható fejlődésre nevelés lehetőségei a magyar óvodában. In Pálfi S. (Ed.), A gyermekre fókuszáló korai nevelés. (pp. 83-98). Debreceni Egyetem Kiadó.

Wells, N. \& Lekies, K. (2006). Nature and Life Course: Pathways from Childhood Nature Experiences to Adult Environmentalism. Children, Youth and Environments, 16(1), 1-25.

WCED. World Commission on Environment \& Development. (1987). The Brundtland report: Our common future. Oxford University Press. https:// sustainabledevelopment.un.org/content/documents/5987our-common-future. pdf (2020.10.27.) 


\section{Darvay, S., Hill, K., Fülöp, V. \& Venyingi, B.}

\section{Environmental sustainability in the nursery}

It is the responsibility of early childhood educators to make sustainability education a part of everyday practice in the nursery. Education for sustainability enables educators and children to promote responsibility, respect the natural environment, and be active participants in the opportunities offered by everyday life. The field of our research is the monitoring of the implementation of environmental sustainability in the nursery, based on the judgment of the university students. We processed the data of 242 students at ELTE TOK, the Faculty of Early Years Education at the ELTE University of Budapest. In the present study, we focus on the following two research topics: which elements of environmental education do early childhood educators incorporate into their daily nursing practice; and we examined the role of health education in the work of the institution. The statements were judged on the fivepoint Likert scale. Based on the evaluation of the results, the issue of environmental sustainability appears to be firmly established in the life of nursery institutions.

Keywords: education for sustainability, institutional approach, health education

Darvay Sarolta: https://orcid.org/0000-0001-9862-015X

Hill Katalin: https://orcid.org/0000-0002-8745-0332

Fülöp Veronika: https://orcid.org/0000-0001-7683-9791

Venyingi Beáta: https://orcid.org/0000-0001-8934-0025 